\title{
OBITUARY
}

\section{J. A. Stewart}

\section{Burma and the Dictionary.}

From a village school, where the ancient classics were taught, at Strichen, in Aberdeenshire, Stewart went to the University of Aberdeen. He graduated with first class honours in Classics in 1903, with University prizes for Latin and for Verse Composition. After leaving the University he was a contributor of verse compositions to the Aberdeen University Review. These compositions were chiefly Greek, and were often translations of his English renderings of folk songs from Burma selected because of resemblances to pieces of Greek literature. He never ceased to take keen pleasure in Greek and Latin literature, and never lost the knack of making neat epigrams. He continued from his undergraduate days a long-standing friendship with Professor John Harrower, the Professor of Greek.

Stewart passed the Indian Civil Service open examination in 1904. He spent his year of probation at Christ Church, where he was awarded an Indian Civil Service scholarship. He went to Burma in 1905. In Lower Burma, where his service began, cultivation was expanding very rapidly to produce rice for export, and unaccustomed social conditions were being created. Junior Indian Civil Servants, as local revenue officers and magistrates, had to work long hours. Stewart became one of those junior officers who were regarded as most capable of the work of an important Sub-division. He served also for five years in the Settlement (Land Revenue) Department.

During the first World War of 1914 to 1918 and the Afghan War Stewart served for four and a half years with the Burma Sappers and Miners, the only regular military force recruited from Burmans at that time, under the able command of his friend Colonel C. W. Bushell, R.E. They were sent to Mesopotamia and Persia, and in the Mesopotamia campaign Stewart's M.C. was one of the honours won by the Burma Sappers at the crossing of the Diala River.

After the period of military service Stewart returned to Burma, and was employed in general administration until his retirement. He was Commissioner of the Magwe Division at the time of the fanatical rebellion which broke out in 1931, mainly in some Districts of Central Burma. The rebellion had to be suppressed by the aid of regular troops. The rebels were guilty of some cruel crimes, and many misguided people suffered imprisonment. Stewart did good service as the chief local civil authority in his Division in that emergency. He was well qualified by energy, common sense, justice, and humanity, and also by his contacts with influential Burmese leaders on the side of law and order. As Commissioner he was able to make long tours which included visits to the Chin Hills in his Division. After four or five years at Magwe and a period of 
leave, he became Commissioner of the Irrawaddy Division, which comprises the delta, for two or three years, until he took leave preparatory to retirement in 1933.

Stewart was never much concerned about official promotion. He was inclined to distrust brilliancy in administration. His aim was to be what he called "a stodgy Deputy Commissioner". He was, in fact, a good officer, whose qualities were always useful, and proved a strong support to peace and order in an emergency like the 1931 rebellion. While he gave their due to official duties, his studies in the language, literature, and history of Burma were more to his liking. He began to develop these interests from the beginning of his service. He soon established a reputation as a linguist, and when in 1910 it was necessary to arrange for the translation of the highly technical Census Instructions for the Census enumerators it was to Stewart that the work was entrusted. The Superintendent of that Census has recorded that he received during the work of enumeration many compliments as to the value of the translations. Stewart in later years undertook many similar feats of translation in military training manuals, terms of modern scientific agriculture, and the like. He took pains from the beginning to master the sounds and idiom of spoken Burmese. His years of service in the Settlement Department would give him good opportunities of studying these among country folk, and he had a penchant for friendly talk with people of all kinds, and especially with children. The Burma Sappers gave him an unusual military and technical vocabulary, which was improved and made exact by his practical experience with them and by his own competence as an amateur craftsman. He read Burmese literature, prose and poetry, whenever time and circumstances allowed. His studies included Pali, the canonical language of religion in Burma, as important for educated Burmans as Latin for Europeans, and also Mon, the language of the people in Lower Burma from whom the Burmans received much of their civilization. Both these languages are, of course, important additions to the resources of a Burmese scholar. His opportunities for studying the languages of the hill tribes were less : but with the help of such manuals as existed he made himself acquainted with their characteristics for the purpose of etymological comparisons. He was well read in Burmese history, and studied from original sources the local history of several of the Districts in which he was stationed. He wrote the historical chapters of the District Gazetteers of the Pegu and Kyaukse Districts. He interested himself also in Burmese antiquities and conducted some archaeological excavation work around the old Mon capital, Pegu. These studies were helped by the friendships which he formed with learned Burmans. Among these friends was U Tin of Pagan, an erudite repository of the traditions of the Burmese royal court and government, in which he had held office, and the author of a large book on Burmese prosody and of Myanma Min Okchok-bon Sadan, an authoritative work describing in five volumes the organization and working of the government under the kings. Stewart had some friendly contact also with the Lèdi Sayadaw, a famous 
preacher and moral leader, and a prolific writer. Stewart regarded him with great respect, collected many of his writings, and read them extensively.

Stewart was one of the earliest members of the Burma Research Society. The Society, which was founded in 1910 , by the initiative mainly of Mr. J. S. Furnivall, continued to issue a journal, to which Stewart contributed articles, until 1941, when it was interrupted by the Japanese invasion. Stewart's contributions were on various literary, linguistic, and historical subjects, and on the folklore of Burma. The Society brought together the work of many people who were active in Burmese studies, and gave them sometimes the advantages of mutual aid and stimulation. Among the members of the Society who contributed actively to the Journal were-besides Mr. FurnivallDr. C. O. Blagden, of the School of Oriental and African Studies (a corresponding member); Mr. R. Halliday, editor of the Mon-English Dictionary; U May Oung, Judge of the High Court, one of the original members; U Shwe Zan Aung, translator of the Pali "Compendium of Philosophy" Abhidhammattha Sangaha, and a highly speculative philologist; Mr. Charles Duroiselle, Superintendent of the Archaeological Survey; U Kyaw Dun, editor of the four volumes of the Anthology of Burmese Literature; Mr. G. E. Harvey, author of the standard history of Burma; Mr. G. H. Luce, Reader in Burmese History in the University of Rangoon, and Professor Pe Maung Tin, Professor of Oriental Studies in the University, who were the collectors and joint editors of the five portfolios of the Inscriptions of Burma ; and Saya Thein of Hmawbi, a prolific writer on Burmese language and history.

Stewart took the principal part from the beginning in the scheme to produce a new Burmese-English Dictionary under the auspices originally of the Burma Research Society, and afterwards of the University of Rangoon. He organized a body of readers (who numbered in all upwards of seventy) and, with some generous help from Mr. H. F. Searle, he bore the main burden of supervising the distribution of books to the readers and the collection and arrangement of about 400,000 word slips recorded by them from 1926 to 1931 . When he took leave in 1933, preparatory to retirement, he was appointed with a colleague to edit the Dictionary in England. The Trustees of the University of Rangoon Endowment Fund undertook to pay the cost of printing. The Dictionary was designed by Stewart on a large scale, and only one part (out of perhaps twenty) had been printed when the work was interrupted by the war of 1939 to 1946 . To help in the preparation of the first part Stewart had obtained a Leverhulme Fellowship grant, which he used to bring U Kin Maung Lat, A.T.M., of the Burma Civil Service, from Burma and to provide for his remuneration for the period of his employment in the work of compilation. About the end of 1943 a proposal came to the Editors from the Government of Burma and the Trustees of the University of Rangoon Endowment Fund that the preparation of the Dictionary should be speeded up with the aid of three Burmese assistants to be provided by means of a grant of $£ 10,000$ from the Government of Burma. The Editors agreed to this proposal. Stewart then erected a well-designed 
building in his garden at Bishop's Stortford, in which the two editors and the three assistants could work together with all the materials and the reference books of the Dictionary under one roof. The building was completed by September, 1945. There was further delay owing to the difficulty of recruiting suitable Burmans from Burma at that time. In April and May 1946 Dr. Hla Pe (now a Lecturer at the School of Oriental and African Studies) and U Thitthila, who were already in England and recently released from employment with the B.B.C., began work in the Dictionary office, and in July U Tet Htoot joined as an unpaid part-time worker. In December 1946, when the work was thus under weigh, the Editors received notice from the University of Rangoon that the Council of the University had resolved that certain steps should be taken with a view to transferring the work of the Dictionary to Burma, where in the opinion of the Council the work of editing, printing, and publishing the Dictionary could best be expedited. The Editors protested against this abrupt change of plan. Correspondence with the University was subject to long delays. The editors declared their intention to carry on with the work until circumstances made a change of the arrangements expedient. Meanwhile, Stewart's health had begun to fail. He was vexed by this controversy, and did not live to see better relations restored.

Stewart's first University conferred the honorary degree of LL.D. on him in 1934, and in the same year he was made C.I.E. on account of his service in Burma.

He married in 1915 the youngest daughter of U An, K.S.M., a Burmese officer of old official stock. He had three sons and one daughter. The two elder sons served in the Royal Air Force in the second World War and both were killed, one flying over Germany and the other over Italy. His wife, Daw Khin Le, his youngest son, and his daughter survive him. Many friends in Burma and in England regret his loss, and he had no enemies.

He had no equal among Europeans in Burmese scholarship. He was judged by educated Burmans to speak Burmese like a Burman. He was a competent critic of Burmese literary style, and was himself master of a good and idiomatic Burmese prose style. He was considered by the University of Rangoon to be a competent External Examiner in Burmese in the examinations of the University.

C. W. Dunn.

\section{The School.}

After a successful career as an able administrator, earning a decoration as a temporary soldier, and an active life overseas given to learning in service, Stewart found another, the one he most desired. He came to us a scholar, a humanist, an Orientalist, a classic Scot.

In his earliest letters to the School from Burma in 1933 he presented himself as a researcher, a teacher, and characteristically a new member of our academic fellowship :- 
“ I am very pleased indeed to have succeeded in my application, and hope to justify my selection. ... Am I to have any pupils, if so, of what service or line of business ?... I do not know if one is expected to wear clothes of a particular cut or colour scheme on duty at the School. Anyhow, I cannot do anything about that till I get home. Unless I were to provide myself with the flowing garments of a Burmese gentleman."

In 1935 he emphasized the priority of his research work, though no one worked harder or to better purpose in the routine duties of his office. Describing his Handbook of Colloquial Burmese, which took on a new shape after his first year at the School, he says, "it contains a sketch of the grammar which is almost entirely original and will, I think, be found to throw light on the real structure of the language. The existing grammars, it may be mentioned, are mere adaptations of the Latin grammar, and force Burmese into an entirely unsuitable framework." This from an accomplished Classical scholar, who was "Latin Secretary" to the School, bears a lesson to all students of Oriental languages, and shows one of the qualities of a many-sided scholar.

In 1936 Stewart was already planning the development of his field of study, and in a letter to the Secretary pointed out that " there are three other languages in which teaching should be offered, Mon, Chin, and Kachin. I am going to offer Mon myself, and I do not at present know of anyone in this country who can teach the others." Stewart himself had passed the Government optional examination in Mon in 1913, and had maintained his interest. He had drawn the main lines for the development of Further Indian studies which the Scarbrough Report endorsed, and there are now five young scholars in training in the Department of Phonetics and Linguistics for Siamese, Cambodian, Annamese, Mon, and the Oceanic languages. Stewart's interests were wide and extended far beyond his specialization. He had a way of showing his shrewd appreciation of the central values of other branches of specialized study. He quickly realized the scope and applications of general linguistics and phonetics, and often made use of a modern transcription himself in writing Burmese before making the fair copy in the Burmese script. "A quick way to good work", he used to say. Being a good lexicographer, he used it to establish pronunciation in the Dictionary.

He was associated with Miss Henderson's studies in the languages of SouthEast Asia, and devoted a most generous share of his precious time during his last year at the School to teaching Mr. Sprigg and directing his studies. An important part of the work now being done in the Department of Phonetics and Linguistics, especially by Miss Henderson and Mr. Sprigg, with assistants from Tibet, Siam, Cambodia, Viet-Nam, and, it is hoped, later on from the Monspeaking districts of Burma and from the Pacific, is in continuation and development of Stewart's work and largely towards building up the revived Department of South-East Asia and the Islands of which he was the Head (from 1st October, 1946) and the future of which he had so much at heart. He was always much more than a departmental man. This he showed as Head of such a wide 
Department as that of India, Burma, and Ceylon, before he was called to South-East Asia. As he once wrote to the Director, " on School matters, I am entirely at your disposal ". He was a wise Senator who hated politics, said so, and behaved accordingly.

To the Senior Common Room he brought a mature humanity and the best of fellowship. He was its first "non-official" Chairman by the unanimous wish of a full meeting, and always enjoyed his place among his colleagues.

He came to the School as Lecturer in Burmese in 1933, was appointed Reader in the University in 1937, Head of the Department of India, Burma, and Ceylon in 1938, became the first professor of Burmese in this country in 1944, and Head of the Department of South-East Asia and the Islands in 1946.

When he was promoted Senior Lecturer he wrote characteristically, "I please myself by construing this as favourable notice of my work". Congratulated on being awarded a Leverhulme Fellowship in 1936, he expressed his appreciation, which was real, and added, "I am in strange company, with a lot of scientific gentlemen".

Nothing could better express the feeling of everyone who knew him at the School, than the reciprocal of what he wrote to the Director in 1938 :-

"My connection with the School has certainly been very valuable to me, and I enjoy association with my colleagues and with my pupils."

J. R. Firth. 


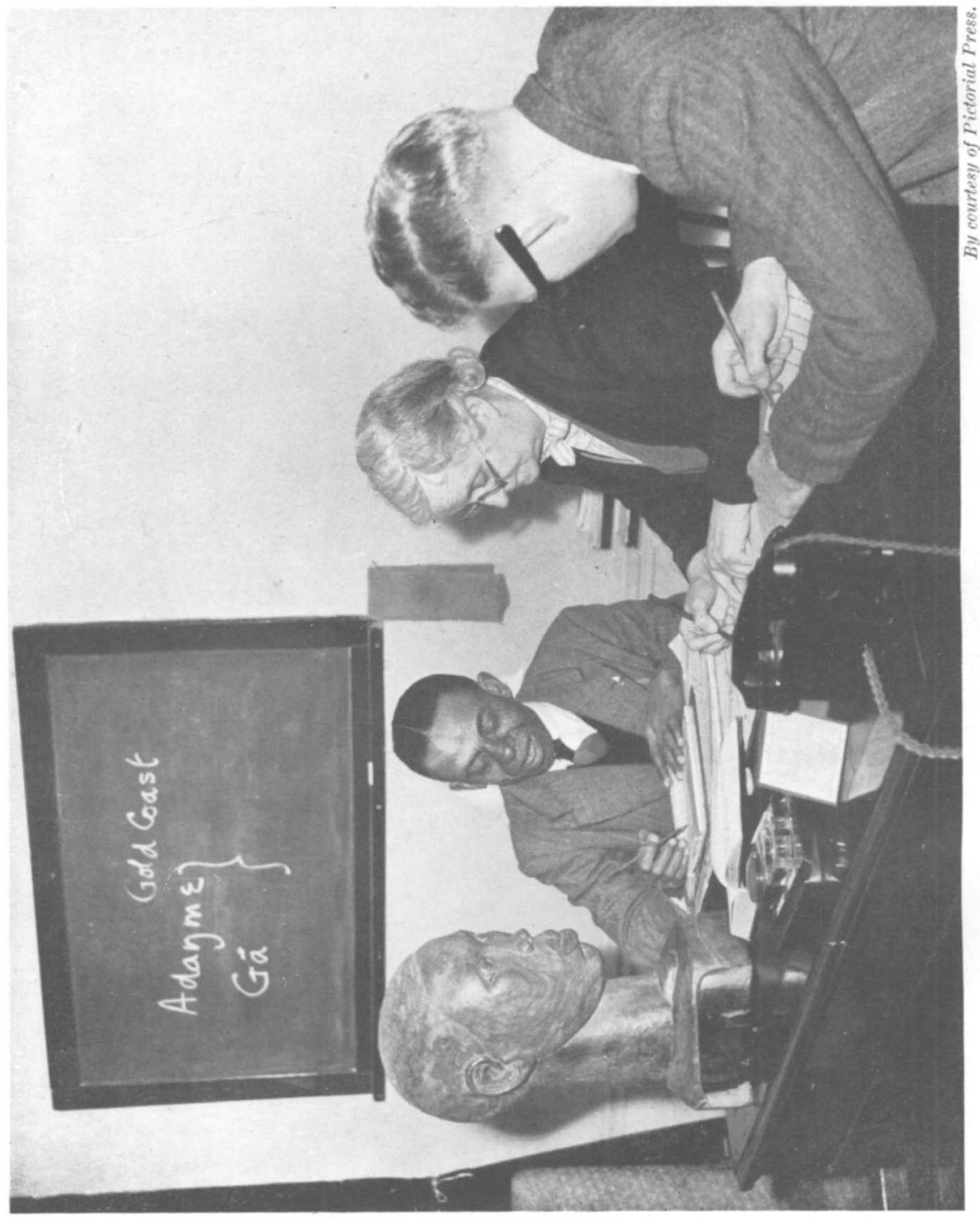

吾)

